\title{
SZTUKA I ARCHITEKTURA DLA II RZECZYPOSPOLITEJ
}

\author{
Andrzej Szczerski \\ (D) http://orcid.org/0000-0003-3594-0070 \\ Uniwersytet Jagielloński w Krakowie
}

\section{ABSTRACT}

\section{ART AND ARCHITECTURE FOR THE SECOND POLISH REPUBLIC}

The period of the Second Polish Republic was a time of dynamic processes of unification and modernisation. They were also reflected in art and architecture. This should not come as a surprise given the fact that Polish artists were involved in the struggle for independence on the battlefields, while they also documented Polish military efforts during the World War I. Later on, they held positions in the state administration, especially in the administrative structures responsible for art patronage and education; finally, they were also active in the field of national propaganda. The authorities of the Second Polish Republic appreciated the importance of modern art, especially that the restoration of independence coincided with a debate about the various definitions of the Polish national style. This debate, which involved supporters of vernacular stylisation and those who promoted modernism, found its complex reflection in the Polish General Exhibition in Poznań in 1929. The exhibition confirmed that the leading role in the process of modernisation was assumed by architecture and urban planning.

Keywords: Second Polish Republic, architecture, art, modernism.

Słowa kluczowe: II Rzeczpospolita, architektura, sztuka, modernizm.

W 1938 roku powstał liczący ponad 40 obrazów olejnych i akwarel cykl prac Rafała Malczewskiego, poświęcony Centralnemu Okręgowi Przemysłowemu, w którym artysta przedstawił malarską interpretację najważniejszych inwestycji zlokalizowanych nie tylko w głównych ośrodkach okręgu, jak Stalowa Wola, ale i działających już wcześniej Mościcach czy w położnym na Sądecczyźnie Rożnowie. Artysta, który fascynował się budową COP i poświęcił mu również ilustrowane felietony publikowane w „Gazecie Polskiej”, nieprzypadkowo zatytułował ten cykl 
Centralny Okręg Przemysłowy - reportaż malarski ${ }^{1}$, prezentując go po raz pierwszy w Instytucie Propagandy Sztuki w Warszawie w grudniu 1938 roku. Podkreślił w ten sposób, że przedstawia dziejącą się właśnie na jego oczach historię, a nie dorobek przeszłości, który można oceniać z dystansu, znając konsekwencje podjętych decyzji. Malczewski postępował podobnie jak Melchior Wańkowicz, towarzyszący mu w podróży po COP, który swoje wrażenia opisał w głośnych reporterskich książkach COP - ognisko sity (1938) i Sztafeta. Książka o polskim pochodzie gospodarczym (1939). Obaj twórcy zwiedzali COP w ramach wizyt organizowanych z polecenia ministra Eugeniusza Kwiatkowskiego, głównego inicjatora inwestycji. Zaproszeni artyści mieli następnie tworzyć dzieła poświęcone COP, wykorzystywane w celach propagandowych i edukacyjnych, doceniające wartość gwałtownych przemian, do jakich dochodziło $\mathrm{w}$ zaniedbanych regionach kraju w rezultacie polityki szybkiej industrializacji prowadzonej przez odrodzoną Rzeczpospolitą. Rafał Malczewski już wcześniej zajmował się tematyką przemysłową i województwem śląskim, nadawał się więc znakomicie na portrecistę COP. Do nowego zadania podszedł z wyraźnym entuzjazmem, przygotowując między innymi liczne studia akwarelowe, rysunkowe czy fotograficzne, wykorzystywane następnie do precyzyjnego komponowania obrazów, zarówno w plenerze, jak i we własnej pracowni. Analizując zachowany do dziś tylko fragmentarycznie cykl, należy zauważyć, że Malczewski przedstawiał COP, posługując się oryginalnym językiem malarskich form, opartym na syntetycznej plamie barwnej i ekspresyjnej kolorystyce, a także kadrowaniu obrazów, przypominających rozwiązania stosowane we współczesnej fotografii awangardowej. W efekcie obrazy mogły przypominać reporterskie zdjęcia, co podkreślała jeszcze specyficzna ikonografia, skoncentrowana zarówno na imponującej skali inwestycji, jak i na jej detalach, na przykład pojedynczych słupach energetycznych, rurociągach czy części większych instalacji przemysłowych. Artysta zrezygnował tym samym z przedstawiania COP jako pozbawionego ludzkiej skali, totalitarnego przedsięwzięcia, zmieniającego całkowicie zastaną rzeczywistość i nieliczącego się z żadnymi ograniczeniami. W obrazach Malczewskiego fabryczne budynki okazują się dopełnieniem naturalnego krajobrazu, a nowoczesne instalacje przemysłowe nie przytłaczają swoim ogromem, zamieniając się w motywy malarskie o niemal onirycznym charakterze, będąc jednocześnie pretekstem do kolorystycznych i kompozycyjnych eksperymentów. Cykl Centralny Okręg Przemysłowy - reportaż malarski odbiegał tym samym od standardowego wówczas patosu w pokazywaniu industrializacji, zwracając uwagę na jej niemal naturalne wpisanie w realia współczesnej Polski, podlegającej szybkim procesom modernizacyjnym. Nowoczesność okazywała się więc nie obcym zjawiskiem, przynoszącym apokaliptyczne zmiany, ale częścią polskiej rzeczywistości, zmieniającej się dzięki ambitnym reformom realizowanym przez polskie państwo.

Obrazy Rafała Malczewskiego świadczą o zaangażowaniu artystów na rzecz odrodzonego państwa polskiego, ale i o tym, że II Rzeczpospolita potrafiła docenić

${ }^{1}$ Por. A. Król, Rafat Malczewski: Centralny Okręg Przemysłowy-reportaż malarski 1938, Stalowa Wola 2008. 
znaczenie sztuki współczesnej dla kształtowania polskiej tożsamości w nowych czasach i wobec odzyskanej niepodległości. Walczyli o nią także sami twórcy, nie tylko swoimi dziełami, ale również z bronią w ręku. Na szczególną uwagę zasługuje fakt, że stanowili oni liczną grupę w Legionach Polskich, a dzięki tworzonym przez nich w trakcie służby wojennej pracom legionowa historia bardzo szybko znalazła swoje miejsce także w kulturze. Pierwsza wystawa sztuki Legionów Polskich, zorganizowana przez Jerzego Mycielskiego pod auspicjami Naczelnego Komitetu Narodowego, została otwarta w krakowskim Pałacu Sztuki już 18 marca 1916 roku². Najwięcej prac, rysunków, grafiki, a także obrazów olejnych i temperowych o małych formatach, w realistyczny sposób pokazywało żołnierzy, pola bitew, mogiły żołnierskie czy codzienne życie na froncie, a rzadkością były formalne eksperymenty nawiązujące do współczesnego ekspresjonizmu. Na tym tle wyróżnia się kompozycja Leopolda Gottlieba Pierwszy odpoczynek (1915), będąca szkicem do akwaforty, oparta na dynamicznej kompozycji i geometryzacji formy. Sam autor należał do najważniejszych twórców sztuki legionowej i pozostawił blisko 1000 portretów oraz scen rodzajowych z walk legionistów, w tym wizerunki Władysława Beliny-Prażmowskiego, Bolesława Wieniawy-Długoszowskiego i Józefa Piłsudskiego ${ }^{3}$. Wśród artystów dokumentujących dzieje Legionów lub poświęcających im swoje prace znaleźli się też tak wybitni twórcy różnych generacji, jak Julian Fałat, Leon Wyczółkowski, Jacek Malczewski, Teodor Axentowicz, Kazimierz Sichulski czy Wojciech Jastrzębowski. Przykładem łączenia artystycznych i żołnierskich życiorysów może być casus Edwarda Rydza-Śmigłego, który studiował malarstwo w krakowskiej Akademii Sztuk Pięknych, a jako legionista narysował znakomity portret Leopolda Gottlieba w Kowlu 9 września 1915 roku (dziś w zbiorach Muzeum Narodowego w Krakowie).

O wsparciu dla niepodległej Rzeczypospolitej świadczą też różnorodne świadectwa zaangażowania artystów na jej rzecz, przede wszystkim w tworzenie polityki informacyjnej, w tym plakatów propagandowych podczas wojny polsko-bolszewickiej, wykonywanych między innymi przez młodą generację twórców, w tym Felicjana Szczęsnego-Kowarskiego oraz Edmunda Bartłomiejczyka. Artyści odpowiadali także za oprawę graficzną znaczących dokumentów państwowych, jak Akt pamiątkowy objęcia Górnego Śląska przez Rząd Rzeczypospolitej Polskiej, wykonany przez górnośląskiego malarza Stanisława Ligonia i podpisany 16 listopada 1922 roku w Katowicach, czy za wykonywanie projektów monet oraz banknotów złotowych emitowanych przez Bank Polski. Środki płatnicze, traktowane jako symbole odrodzonego państwa i świadectwo jego ekonomicznego rozwoju, projektowali między innymi Wacław Borowski, Julian Pałka, Henryk Tomaszewski, Edward Wittig, a także Józef Mehoffer, który w 1929 roku wygrał konkurs na projekt banknotu stuzłotowego. Na jego awersie w wersji z 1932 roku znalazły się wizerunek księcia

${ }^{2}$ Por. W. Milewska, M. Zientara, Sztuka Legionów Polskich i jej twórcy 1914-1918, Kraków 1999.

${ }^{3}$ P. Wilkosz, Zarys historii kolekcji sztuki legionowej w Muzeum Narodowym w Krakowie [w:] Sztuka Legionów Polskich, red. A. Jurkiewicz-Zejdowska, P. Wilkosz, kat. wystawy, Muzeum Narodowe w Krakowie, Kraków 2017, s. 15. 
Józefa Poniatowskiego i sylwetka Merkurego w locie, a na rewersie dąb rosnący na Kamiennej Górze w Gdyni, z widocznym w tle Bałtykiem i nadmorską plażą, flankowany przez postaci alegoryczne, Merkurego oraz Fortunę. Znak wodny wyobrażał popiersie królowej Jadwigi, a banknot drukowany w Polskiej Wytwórni Papierów Wartościowych w Warszawie uznawany jest dziś za najpiękniejszy polski pieniądz papierowy ${ }^{4}$. Warto wreszcie pamiętać, że artyści włączali się w działania rządu na rzecz wspierania życia artystycznego w odrodzonym kraju. Na czele utworzonego 5 grudnia 1918 roku Ministerstwa Sztuki i Kultury stał w 1919 poeta i krytyk Zenon Przesmycki, a po przekształceniu ministerstwa w Departament Sztuki w Ministerstwie Wyznań Religijnych i Oświecenia Publicznego w latach 1922-23 kierował nim Julian Fałat.

Wraz z powstaniem niepodległego państwa rozpoczęła się niezwykle dynamiczna i intensywna debata na temat stylu narodowego, który mógłby wyrazić kulturową tożsamość Polaków, a jednocześnie ich odrębność w ramach kultury europejskiej. W latach 20. zarysowały się w niej dwie wyraziste postawy, pierwsza wskazująca na konieczność odnajdywania inspiracji w tradycji ludowej i wernakularnej, druga sugerująca, że należy adaptować wzorce modernistyczne, dostosowując je do polskiej specyfiki i potrzeb. Egzemplifikacją tych różnic stała się prezentacja sztuki i architektury na Powszechnej Wystawie Krajowej (PWK) w Poznaniu w 1929 roku. Wśród jej twórców istotną rolę odegrał historyk sztuki Mieczysław Treter, współautor polityki kulturalnej w czasach II RP, między innymi kierujący od 1926 roku Towarzystwem Szerzenia Sztuki Polskiej Wśród Obcych i jeden ze współzałożycieli Instytutu Propagandy Sztuki w Warszawie (1930)5. W katalogu Działu Sztuki na PWK pisał on, że „nie sukcesy polityczne ani korzystne ekonomiczne traktaty kształtują duchową fizjonomię narodu i wzbudzają szacunek u świata, lecz przede wszystkim własna odrębna kultura, literatura i nauka, muzyka i sztuki plastyczne". Sztuka świadczyć miała o dostojeństwie narodu, co więcej, Mieczysław Treter był przekonany, że więcej polskiego narodowego geniuszu można odnaleźć w sztuce niż w produkcji przemysłowej i rolnej. Zdając sobie sprawę ze znaczenia dyplomacji kulturalnej i odwołując się do pojęcia stylu, Treter twierdził, że sztuka wyraża ducha narodowego i za pomocą cech odrębnych określa fizjonomię narodu oraz jego miejsce wśród innych. Dodawał przy tym, że ,zadanie takie może jednak spełnić tylko sztuka, która posiada swój własny, odrębny styl", opierając się na narodowych zbiorowych myślach i uczuciach, a nie przez naśladowanie obcych zdobyczy, dzięki czemu wypracować może swoją odrębną formę 7 .

${ }^{4}$ A. Jaw oru cka-Drath, Józef Mehoffer, banknot 100-zlotowy, nota katalogowa [w:] \#dziedzictwo, red. A. S zc zers ki, kat. wystawy, Muzeum Narodowe w Krakowie, Kraków 2017, s. 548.

5 Por. D. Wasilewska, Mieczystaw Treter: Estetyk, krytyk sztuki oraz „szara eminencja” międzywojennego życia artystycznego w Polsce, Kraków 2019.

${ }^{6}$ M. Treter, Dziat Sztuki na P.W.K. w Poznaniu i dziesięciolecie sztuki polskiej 1918-1928, ,Sztuki Piękne", R. V, VIII-IX 1929, s. 293.

${ }^{7}$ M. Treter, Polska sztuka dekoracyjna. Z powodu ksiązki Jerzego Warchałowskiego, „Warszawianka” 1928, nr 98, s. 5; cytat za: D. Wa silew sk a, op. cit., s. 61. 
Poznańska wystawa i jej poszczególne pawilony pokazały zróżnicowanie architektonicznych form oraz ich ideowych znaczeń, wykorzystywanych w celu prezentacji osiągnięć II RP. Realizując projekty na zamówienie rządowe, między innymi Halę Reprezentacyjną i reprezentacyjny dziedziniec, naczelny architekt wystawy Roger Sławski posługiwał się niemal wyłącznie formami klasycyzującymi, nawiązując częściowo do architektury polskiej XVIII wieku . Z kolei Pałac Rządowy, zaadaptowany na potrzeby wystawy gmach Instytutu Chemii Uniwersytetu Poznańskiego projektu Edwarda Madurowicza z 1920 roku, Sławski ukończył, dodając neorenesansową attykę, którą współczesny krytyk Stanisław Woźnicki identyfikował $\mathrm{z}$ „renesansem polskim”. Tenże krytyk uznał Pawilon Polonii Zagranicą projektu Sławskiego za bliski formom stanisławowskiego pałacu Na Wodzie w Lazienkach ${ }^{10}$. Wykorzystanie klasycyzującego kostiumu stylistycznego uznać można za nawiązanie do tradycyjnego utożsamiania klasycyzmu ze stylem państwowych budynków publicznych, sięgającego jeszcze końca XVIII wieku w Europie i Stanach Zjednoczonych. W II RP najważniejszym przykładem tej tendencji był gmach Województwa i Sejmu Śląskiego w Katowicach (Kazimierz Wyczyński, Stefan Żeleński, Piotr Jurkiewicz, Ludwik Wojtyczko, 1923-1929). Ponadto klasycyzm, jako styl kojarzony z dziedzictwem kultury śródziemnomorskiej, mógł być także dowodem na przynależność Polski do cywilizacji zachodnioeuropejskiej i kontrastować z tradycją gotycką, w Poznaniu i Wielkopolsce w oczywisty sposób kojarzącą się z niemieckim zaborcą. Jak twierdzi Barbara Zwolanowska, Sławski nawiązywał także do „stylu dworkowego", traktowanego nadal w latach 20. jako polski styl narodowy ${ }^{11}$.

O poszukiwaniach narodowego modernizmu świadczył przede wszystkim pawilon Związku Hut Szklanych autorstwa Jana Golińskiego i Henryka Lagowskiego. Zastosowano tu nowoczesną stalową konstrukcję, a ściany wykonano z różnokolorowych tafli szklanych. Jednolitość stylistyczną osiągnięto, nadając szklanym elementom i modułom konstrukcyjnym geometryczne kształty, w tym charakterystycznych trójkątów. Nawiązano w ten sposób do stylistyki Pawilonu Polskiego autorstwa Józefa Czajkowskiego, który z powodzeniem reprezentował kraj na Międzynarodowej Wystawie Sztuk Dekoracyjnych i Przemysłu Artystycznego w Paryżu w 1925 roku i był świadectwem trwania tradycji Warsztatów Krakowskich. Podobnie jak w Paryżu, najbardziej widocznym elementem pawilonu na PWK była przeszklona wieża, której konstrukcja nawiązywała do formy kryształu. Analogiczne formy, łączące nawiązania do sztuki ludowej i współczesnego art déco, stanowiące spójną koncepcję stylistyczną promowaną przez komisarza paryskiej wystawy Jerzego Warchałowskiego, w połowie lat 20. zaczęto utożsamiać z reprezentacyjnym stylem

${ }^{8}$ Niniejszy fragment dotyczący PWK został oparty na moim artykule Pytania o sztuke dla II Rzeczypospolitej. Powszechna Wystawa w Poznaniu w 1929 roku, opublikowanym w: A. S zc zer ski, Cztery nowoczesności. Teksty o sztuce i architekturze polskiej XX wieku, Kraków 2015, s. 41-62.

${ }^{9}$ S. Woźnicki, Zabudowa terenów Powszechnej Wystawy Krajowej w Poznaniu, „Architektura i Budownictwo", R. V, 1929, z. 1, s. 18.

${ }^{10}$ Ibidem, s. 20.

${ }^{11}$ B. Zwolanowska, Architektura Powszechnej Wystawy Krajowej w Poznaniu w roku 1929, „Rocznik Historii Sztuki” 1976, t. XI, s. 198. 
państwowym II RP ${ }^{12}$. Na tle wystawy wyróżniały się pawilony, gdzie dominował modernizm, zarówno w umiarkowanym, jak i awangardowym wydaniu, autorstwa między innymi przedstawicieli młodej generacji architektów z grupy „Praesens”. Na Terenach Zachodnich zlokalizowano Pawilon Nawozów Sztucznych autorstwa Szymona Syrkusa, złożony z trzech przeszklonych prostopadłościanów. Jego ascetyczne formy były wyrazem funkcjonalizmu, a także popisem umiejętności konstrukcyjnych, dzięki czemu montaż metalowego szkieletu pawilonu wraz z wieżą o wysokości 22 metrów trwał zaledwie 15 dni. Nowatorski charakter miał również pawilon "Centrocementu” Bohdana Lacherta i Józefa Szanajcy, ufundowany przez Związek Polskich Fabryk Portland Cementu. Oparty został na planie połączonych prostokąta i koła, wykonano go z betonu i szkła z akcentem wertykalnym w postaci wieży, na której umieszczono także reklamę cementu. Pozbawiona dekoracji całość była kolejnym przykładem funkcjonalizmu i śmiałego wykorzystania możliwości konstrukcyjnych nowoczesnych materiałów budowlanych. Elegancją wyróżniał się natomiast pawilon firmy krawieckiej Bogusława Hersego, autorstwa Bohdana Pniewskiego, złożony z trzech zestawionych pod kątem prostym prostopadłościanów z półkolistą przeszkloną witryną. Finezyjne zestawienie prostopadłościennych brył i zaokrąglonej wieży charakteryzowało z kolei Pawilon Ministerstwa Poczt i Telegrafów (Julian Puterman, Antoni Miszewski).

Pluralizm form odnaleźć można było także na wystawie w Pałacu Rządowym, gdzie zaprezentowano osiągnięcia rządu polskiego i poszczególnych ministerstw. Jak podkreśliła Iwona Luba, wystawy miały precyzyjnie zaplanowaną oprawę plastyczną, którą koordynowała specjalna komisja artystyczna, a jej realizację powierzono zarówno twórcom art déco, jak i „nowatorom o konstruktywistycznej proweniencji, doświadczonym w zakresie sztuki dekoracyjnej i użytkowej, a także w projektowaniu wnętrz" "'. Decyzja ta została świadomie podjęta przez Departament Sztuki w Ministerstwie Wyznań Religijnych i Oświecenia Publicznego, który odpowiadał za kształt wystawy rządowej, podobnie jak w przypadku realizacji architektonicznych promując rozmaite przykłady sztuki nowoczesnej, w tym awangardę. Na wystawie znalazły się więc obok siebie plakaty, plansze informacyjne, makiety i stoiska wystawowe autorstwa zarówno artystów z klasycyzującej bliskiej art déco grupy „Rytm”, kontynuatorów Warsztatów Krakowskich, jak Jan Koszczyc-Witkiewicz i Wojciech Jastrzębowski, umiarkowanie modernistyczne prace Tadeusza Gronowskiego, jak i awangardowe projekty członków „Praesens”. Jej członkowie zaprojektowali między innymi wystawę Ministerstwa Skarbu, monopoli państwowych czy Banku Rolnego (Władysław Strzemiński, Katarzyna Kobro, Henryk Stażewski, Szymon Syrkus, Henryk Czerny i in. $)^{14}$. Na uwagę zasługiwały także realizacje Karola

${ }_{12}$ Por. m.in. I. Huml, Polish Art Déco, the Style of Regained Independence (the 1920s) [w:] The Art of the 1920s in Poland, Bohemia, Slovakia and Hungary, Niedzica Seminars, October 19-22 1989, Kraków 1991, s. 11-19 oraz A. Si r ra dzk a, Art Déco jako styl państwowy II Rzeczpospolitejarchitektura, wnętrza ,Ładu” i produkcja przemysłowa [w:] Encyklopedia Art Déco, Warszawa 2002, s. 207-220.

13 I. Luba, op. cit., s. 264.

14 „Praesens”, V 1930, nr 2, s. 177-179. 
Kryńskiego, na przykład fotomontaże poświęcone bezpieczeństwu pracy na wystawie Ministerstwa Pracy i Opieki Społecznej czy fotomontaże i infografika w dziale monopolu spirytusowego ${ }^{15}$.

Należy podkreślić, że obok pawilonów wystawienniczych eksponowane miejsce na PWK przyznano sztuce, zarówno sztukom pięknym, jak i wzornictwu. Dział Sztuki, z ponad 2600 pracami około 700 współczesnych artystów, znalazł się w Pałacu Sztuki, usytuowanym w bezpośrednim i prestiżowym sąsiedztwie Pałacu Rządowego, nazywanym w prasie Muzeum Współczesnej Sztuki Polskiej. Komisarzem Działu Sztuki został profesor warszawskiej Akademii Sztuk Pięknych Tadeusz Pruszkowski, zastępując Jerzego Warchałowskiego, który zrezygnował z uwagi na brak żądanych funduszy na organizację wystawy. Finanse były tylko jednym z powodów rezygnacji, drugim - krytyka jego koncepcji wystawienniczej zdominowanej przez nawiązania do rzemiosła artystycznego i rodzimych wątków w sztuce polskiej, kontynuującej przesłanie paryskiej wystawy z 1925 roku. Pruszkowski nie powtórzył programu z Paryża, prezentując teraz, zgodnie z założeniem ,powszechności”, wiele tendencji artystycznych, z którymi II RP mogła się utożsamiać, w tym najnowsze, które zyskały na znaczeniu pod koniec lat 20. Zrezygnował także z pokazu sztuki ludowej, dla której przeznaczono osobny dział, gdzie prezentowano „sztukę i przemysł ludowy". Integralną częścią wystawy był natomiast pokaz XIX-wiecznych korzeni „szkoły polskiej”, z obrazami Piotra Michałowskiego, Józefa Chełmońskiego, Jana Stanisławskiego, Juliana Fałata, Stanisława Wyspiańskiego i przede wszystkim Jana Matejki. Jedną z największych sal w Pałacu Sztuki przeznaczono na monumentalną ekspozycję kartonów witrażowych Józefa Mehoffera i rzeźb Xawerego Dunikowskiego. Rozłożenie akcentów wskazywało na dominację nurtów nieawangardowych i tradycjonalistycznych. Na wystawie w Pałacu Sztuki znaleźli się obok siebie twórcy sztuk plastycznych zrzeszeni między innymi w Towarzystwie Artystów Polskich „Sztuka”, kultywującym tradycje malarstwa z przełomu XIX i XX wieku, klasycyzujący malarze z Wileńskiego Towarzystwa Artystów Plastyków oraz bliżsi art déco artyści z grupy „Rytm”, ugrupowania kolorystów hołdujących postimpresjonizmowi „Jednoróg” i „Plastyka”, realiści inspirujący się malarstwem holenderskim XVII wieku z Bractwa św. Łukasza, a także konserwatyści z warszawskiego zrzeszenia „Pro Arte". Umiarkowaną nowoczesność w dziedzinie wzornictwa i architektury wnętrz reprezentowali członkowie spółdzielni „Ład”. Dla ugrupowań tych „sztuka polska” miała być nowoczesna dzięki reinterpretacji własnej tradycji w dialogu z międzynarodowym modernizmem. Pruszkowski zaprosił na wystawę także awangardową grupę „Praesens”, której obecność w Pałacu Sztuki świadczyła o uznaniu dla jej osiągnięć, nietraktowanych tylko jako użyteczne narzędzie w realizacji informacyjnych wystaw w pawilonach. O tym, że sztuka II RP musi być nowoczesna, pisał przy okazji recenzji z PWK Mieczysław Treter, twierdząc: „tylko twórczość o wysokim napięciu, odpowiadająca swym artystycznym poziomem sztuce europejskiej i jej ostatnim, najwyższym sukcesom, twórczość, w której polski temperament plemienny ujawnia się nie w temacie tylko, lecz w przedziwnej, na własny sposób skonstruowanej formie

${ }^{15}$ I. L u ba, op. cit., s. 265-269 - tam szczegółowy opis wystawy rządowej na PWK. 
- godna jest nosić miano narodowej"16. O tym, że nie oznaczało to akceptacji dla konstruktywistycznej abstrakcji, świadczą inne słowa Tretera, który uważał, że sztuka polska dąży do realnego ujmowania przedmiotów i zjawisk, a tym samym brak w niej „,czysto spekulacyjnych, na abstrakcji opartych pomysłów i tematów”"17. Mimo to przyjęcie zaproszenia pokazywało, że skupiona w grupie „Praesens” awangarda gotowa była utożsamić się z państwem polskim oraz uczestniczyć w kształtowaniu polityki kulturalnej, aby $\mathrm{w}$ ten sposób realizować swoje programowe postulaty ${ }^{18}$. Warto dodać, że o tym otwarciu na różnorodne nowatorskie eksperymenty świadczyła także obecność na wystawie działów promujących modernistyczne projektowanie graficzne „Sztuka Graficzna Stosowana”, „Piękna Książka”, a także działu „Architektura i Fotografia Artystyczna". Na wystawie znalazło się także kilka rzeźb ustawionych w otwartej przestrzeni przed pawilonami, w tym „Lotnik” Edwarda Wittiga usytuowany przez Pałacem Sztuki.

Akceptacja modernizmu na wystawie poznańskiej jako jednego z elementów autoprezentacji II RP była wynikiem utożsamienia go z nowoczesnością i współczesną kulturą zachodnią, z którą Polska chciała się identyfikować19. W katalogu wystawy pisano wprost, iż Polska, położona na granicy dwu światów i dwu kultur, doprowadzić ma do zwycięstwa idee Zachodu, idee kultury łacińskiej. W kontekście promocji procesów modernizacyjnych widzieć można także realizację na PWK osobnego działu poświęconego dorobkowi zawodowemu i artystycznemu kobiet, a co za tym idzie, podkreślenie znaczenie kobiet dla „nowego państwa” jako aktywnych zawodowo, świadomych uczestniczek życia społecznego. Nawiązano w ten sposób do tradycji odrębnych pawilonów kobiecych, które pojawiały się na analogicznych wystawach już w XIX wieku, jak kobiecy pawilon autorstwa Sophie G. Hayden, absolwentki Massachusetts Institute of Technology na World's Columbian Exposition w Chicago w 1893 roku. W Polsce pierwsze wystawy poświęcone efektom aktywności zawodowej kobiet odbywały się w warszawskim Muzeum Przemysłu i Rolnictwa w 1877 i 1889 roku $^{20}$.

Jak podkreśla Joanna Sosnowska, która poddała szczegółowej analizie dotyczące działalności kobiet pawilony, pierwotnie planowano budowę jednego pawilonu poświęconego całej społeczności polskich kobiet, ale w trakcie przygotowań z powodów politycznych doszło do podziału ${ }^{21}$. Odrębny „Pawilon Ziemianek i Włościanek” zbudowała grupa, która nie utożsamiała się z kobietami związanymi ze środowiskiem

${ }_{16}$ M. Treter, Dziat Sztuki na P.W.K. w Poznaniu i dziesięciolecie sztuki polskiej 1918-1928, „Sztuki Piękne”, R. V, VIII-IX 1929, s. 321.

${ }_{17}$ M. Treter, Sala Honorowa [w:] Katalog Działu Sztuki na Powszechnej Wystawie Krajowej w Poznaniu w 1929 roku, Poznań 1929, s. 1-4.

${ }^{18} \mathrm{O}$ działalności Władysława Strzemińskiego w tym czasie por. A. Turowski, Budowniczowie świata, Kraków 2000, s. 129-131.

19 Por. opinie w „Tygodniku Ilustrowanym” 1929, nr 21: ,Jeżeli jednak patrzeć będziemy na wystawę poznańską pod kątem powszechnego dzisiaj dążenia do nowoczesności, to będziemy musieli zgodzić się na to, że uczyniono tu wszystko, aby dorównać zachodowi europejskiemu".

${ }^{20}$ Por. J. Sosnowska, Poza kanonem. Sztuka polskich artystek 1880-1939, Warszawa 2003, s. $221-234$.

${ }^{21}$ Ibidem, s. 223. 
legionowym i PPS-em, tworzącymi od 1928 roku Związek Pracy Obywatelskiej Kobiet oraz Klub Polityczny Kobiet Postępowych. Oba kobiece pawilony miały radykalnie odmienne formy. „Pawilon Ziemianek i Włościanek”, zaprojektowany przez poznańskiego architekta Stanisława Mieczkowskiego na terenie E, utrzymano w formach klasycyzującego dworku, przypominającego rozwiązania stosowane w „stylu dworkowym”22. Drugi kobiecy pawilon, nazwany „Pawilonem Pracy Kobiet”, był przykładem architektury awangardowej. Powstał w wyniku zamkniętego konkursu, do którego zaproszono tylko kobiety: Mirutę Słońską, Marię Buckiewiczównę i Anatolię Hryniewiecką-Piotrowską. Warto podkreślić, że pod koniec lat 20. w Polsce pracowało już kilka kobiet wykonujących zawód architekta, do tej pory niemal w całości zdominowany przez mężczyzn, a jak twierdzi Joanna Sosnowska, na początku lat 30. było ich co najmniej 20. Ten symbol emancypacji zawodowej świadczył o gotowości ówczesnego społeczeństwa polskiego na akceptację takich zmian i wszechstronnej działalności kobiet, w tym na polu architektury. Jury konkursu, złożone z uznanych autorytetów architektury: Franciszka Lilpopa, Rudolfa Świerczyńskiego i Stefana Sienickiego, wybrało do realizacji projekt Anatolii Hryniewieckiej-Piotrowskiej, młodej absolwentki Politechniki Warszawskiej. Pawilon o modernistycznych formach, zbudowany na planie prostokąta $\mathrm{z}$ aneksami, mieścił dwie sale wystawiennicze, pomieszczenia służbowe, a zgodnie z wymogami konkursowymi posiadał także duże witryny i kawiarnię na dachu. Wyróżniała go też kolorystyka, szare i żółte ściany, świadczące o tym, że autorka chciała wziąć udział w toczącej się wówczas dyskusji na temat odpowiednich kolorów dla modernistycznej architektury. Pawilon Pracy Kobiet, promując nowy wizerunek kobiety, nie kwestionował tradycyjnych funkcji pełnionych przez nią w rodzinach, a szerzej w życiu społecznym. Znajdowały się tu działy poświęcone pracy pracownic umysłowych, w instytucjach użyteczności publicznej, w służbie zdrowia, w przemyśle, w chałupnictwie i rzemiośle, pracy najemnej na roli, służbie dworskiej i domowej. W dziale gospodarstwa domowego można było zapoznać się z modelem wzorowej kuchni i wieloma wynalazkami mającymi ułatwiać pracę domową ${ }^{23}$. W Pawilonie zaprezentowano również działalność artystyczną, ale próżno było szukać tu sztuki awangardowej. Na wystawie przygotowanej przez Zofię Stankiewiczówną, artystkę bliską tradycji malarstwa końca XIX wieku, dominowały tradycjonalistyczne malarstwo i grafika, a na tym tle wyróżniały się prace Olgi Boznańskiej. Wynikało to również z niechęci wielu współczesnych artystek do pokazywania swoich prac w kontekście tylko kobiecym, co uznawały za ograniczenie. Z tego też względu prawdopodobnie w wystawie nie wzięła udziału ciesząca się wielką popularnością Zofia Stryjeńska, której prace znalazły się w innym miejscu wystawy, w Pawilonie Wydawniczym²4.

Powszechna Wystawa Krajowa w Poznaniu potwierdziła, że wśród najważniejszych osiągnięć II RP należy bez wątpienia wskazać powstającą wówczas architekturę i urbanistykę. W konsekwencji można uznać, że to właśnie działalność

22 J. S o snowska, op. cit., s. 230.

${ }_{23}$ M. Ruszczyńska, Wystawa pracy kobiet [w:] Powszechna Wystawa Krajowa $w$ Poznaniu w roku 1929, dzieło zbiorowe pod kierownictwem dr. Stanistawa Wachowiaka, t. IV, Poznań 1930, s. 71.

${ }^{24}$ J. So snows ka, op. cit., s. 233. 
architektoniczna wpłynęła $\mathrm{w}$ istotny sposób na wszechstronny awans cywilizacyjny odrodzonego kraju, ale także stała się widocznym znakiem rozwoju Polski i jednoczenia ziem funkcjonujących dotąd w trzech zaborach. Na docenienie zasługuje przede wszystkim skala rozwoju, co dostrzec można z perspektywy zarówno największych miast, jak i regionów prowincjonalnych. Te pierwsze, w tym Warszawa, Łódź, Lwów i Kraków, powiększyły swój obszar, rozbudowały często najbardziej podstawową infrastrukturę, jak kanalizacja czy system drogowy, a także zyskały nowe dzielnice mieszkaniowe, gmachy publiczne czy urządzenia sportowe. W tych drugich dochodziło do istotnej poprawy zastanej tkanki architektonicznej, ale i do fundamentalnych zmian przeobrażających je w ważne ośrodki o znaczeniu ogólnokrajowym, czego przykładem mogą być nie tylko wspominane inwestycje w COP, ale także powstanie Gdyni, sieć nowych uzdrowisk i ośrodków wypoczynkowych nad Bałtykiem, zwłaszcza na Półwyspie Helskim, jak Jurata i Jastarnia, czy awans Zakopanego do roli zimowej stolicy Polski dzięki nowym inwestycjom turystycznym, leczniczym i sportowym. II Rzeczpospolita przeprowadziła także wiele inwestycji na terenie autonomicznego województwa śląskiego, rozbudowując miasta, zakładając nową sieć szkół czy rozwijając istniejące uzdrowiska, umożliwiając powstanie tak nowatorskich w skali całej Europy Środkowo-Wschodniej realizacji, jak Muzeum Śląskie projektu Karola Schayera z 1934 roku. W Wiśle w 1931 roku stanęła rezydencja ofiarowana przez województwo śląskie prezydentowi Polski Ignacemu Mościckiemu. Projektant budynku Adolf Szyszko-Bohusz połączył modernistyczne formy bryły z kamienną okładziną, pochodzącą z miejscowego kamieniołomu, tym samym nadając całości neoromantyczny charakter. Wybitnym osiągnięciem były wnętrza Zamku Prezydenta, zaprojektowane przez Szyszko-Bohusza, Andrzeja Pronaszkę i Włodzimierza Padlewskiego, wyposażone w meble z metalowych rurek, nieustępujące wyrafinowaniem najlepszym współczesnym projektom w Europie i Stanach Zjednoczonych ${ }^{25}$. Architektura II RP mogła także poszczycić się wieloma wybitnymi pojedynczymi realizacjami, które weszły do kanonu historii architektury polskiej. Zaliczają się do nich monumentalne inwestycje publiczne (Muzeum Narodowe w Warszawie, proj. Tadeusz Tołwiński, Antoni Dygat, Stefan Bryła, 1926-1938) i prywatne (willa Barbary i Stanisława Brukalskich na warszawskim Żoliborzu, 1927-1929). Co jednak istotniejsze, ówcześni architekci potrafili wyznaczyć wysokie standardy dla powstającej na dużą skalę i w szybkim tempie zabudowy mieszkaniowej. Intensywny rozwój architektoniczny możliwy był nie tylko dzięki istniejącemu w Polsce systemowi kształcenia architektów i inżynierów, bazującemu na dwóch politechnikach w Warszawie i Lwowie, ale również za sprawą odpowiednich regulacji prawnych i podatkowych ułatwiających działalność inwestorom i wykonawcom. Można wśród nich wymienić ustawę o rozbudowie miast z 1925 roku, system kredytów budowlanych udzielanych przez Bank Gospodarstwa Krajowego czy prawo spółdzielcze

${ }^{25}$ S. Świerz Zaleski, Zameczek $w$ Wiśle, „Sztuki Piękne” 1931, t. 7, s. 59-61. Por. też: A. Kostrzyńska-Miłosz, Polskie meble 1918-1939. Forma-funkcja-technika, Warszawa 2005, s. $150-155$. 
pozwalające realizować przede wszystkim inwestycje mieszkaniowe zarówno dla zamożnych grup zawodowych, jak i dla ubogich mieszkańców miast.

Akceptacja sztuki i architektury współczesnej nie oznaczała zgody tylko na modernizm i awangardę, których nie wahano się nawet nobilitować prestiżowymi realizacjami, jak pawilon polski na wystawie międzynarodowej w Paryżu w 1937 roku (proj. Stanisław Brukalski, Bohdan Pniewski, Bohdan Lachert, Józef Szanajca). Widoczny na poznańskiej wystawie pluralizm charakteryzował życie artystyczne w II RP przez całą jej historię, czego przykładem może być także akceptacja tendencji tradycjonalistycznych, w tym działalności kolorystów, twórców oryginalnej koncepcji malarstwa sięgającego do tradycji postimpresjonizmu. To właśnie artyści z tego kręgu zostali wybrani przez Adolfa Szyszko-Bohusza, odpowiedzialnego za odnowienie Zamku Królewskiego na Wawelu, aby namalować dekorację plafonów rekonstruowanych sal zamkowych na I i II piętrze. W pierwszej kolejności powstały malowidła w Kurzej Stopce, autorstwa Felicjana Szczęsnego Kowarskiego w 1929 roku, a kolejne wykonali między innymi Zygmunt Waliszewski, Jan Cybis i Zbigniew Pronaszko. Zamek, który miał pełnić funkcje zarówno muzealne, jak i siedziby Prezydenta RP, stawał się w ten sposób w części także galerią sztuki współczesnej, radykalnie inną od tej w zamku $\mathrm{w}$ Wiśle. $\mathrm{Z}$ kolei $\mathrm{w}$ pawilonie polskim na wystawie światowej w Nowym Jorku w 1939 roku (proj. Jan Cybulski, Jan Galinowski) czołowe miejsce przyznano twórcom z Bractwa św. Łukasza, których wielkoformatowe obrazy poświęcone historii Rzeczypospolitej namalowano w estetyce monumentalnego realizmu, charakterystycznego dla lat 30 . Nowojorska prezentacja obejmowała jednak także modernistyczne wzornictwo, w tym zwłaszcza nowatorskie projekty wnętrz, odnoszące się do idei modernizmu organicznego, wykorzystującego formy i materiały zaczerpnięte z natury ${ }^{26}$. Dwoistość ta wynikała z przemian na scenie artystycznej końca lat 30., a jak podkreśla Katarzyna Nowakowska-Sito, w drugiej dekadzie niepodległości twórcy zaangażowani w politykę kulturalną państwa, zwłaszcza Władysław Skoczylas i Tadeusz Pruszkowski, „zaczęli lansować nową koncepcję sztuki »narodowej« - rozumianej tym razem nie w kategoriach stylu, a w sensie zdolności artysty do nawiązywania kontaktu z szeroką publicznością"27. W efekcie powstawać miało zarówno malarstwo tematyczne, jak i wysokonakładowa grafika czy sztuka, która „wdarła się na ulicę [...] wszędzie, gdzie żyje i pracuje współczesny człowiek", a Skoczylas uważał, że współczesne państwo powinno wspierać artystów tworzących druki oficjalne, znaczki pocztowe, godła czy plakaty ruchu turystycznego ${ }^{28}$.

W II RP sztuka i architektura, mimo istotnych różnic ideowych i artystycznych wpływających na różnorodność życia kulturalnego, opowiedziały się po stronie modernizacyjnych przemian, wspierając podejmowane $\mathrm{w}$ tym zakresie

${ }^{26}$ K. Nowakowska, Pawilon polski na nowojorskiej wystawie światowej 1939-1940, Warszawa 2013.

${ }^{27}$ K. Nowakowska-Sito, Artyści i sztuka w nowym państwie [w:] Wyprawa w 20-lecie, red. Katarzyna Nowakowska-Sito, kat. wystawy, Muzeum Narodowe w Warszawie, Warszawa 2008, s. 50.

${ }^{28}$ Ibidem, s. 51. 
działania państwowe, a przede wszystkim wyznaczając nową ,granicę współczesności” w historii kultury polskiej. W niepodległym państwie doceniono, że nowoczesność i związane z nią procesy modernizacyjne są integralną częścią polskiej tożsamości i wyrażają się nie tylko przez imitację i dialog z ,centrami”, ale też przez wewnętrzną dynamikę i przemiany kultury polskiej, a przede wszystkim toczony w jej ramach spór o najbardziej adekwatny model nowoczesności, którą w Polsce warto budować29. Odzyskana niepodległość oznaczała także rozpoczęcie procesu poszukiwania podmiotowego miejsca w historii nowoczesności, która do tej pory kojarzyć się mogła tylko z czasami rozbiorów i utrzymywaniem półperyferyjnego statusu ziem polskich w ramach rozbiorowych mocarstw, a nie prowadzeniem przemyślanej polityki nowoczesnych reform. Modernizacyjne wzorce kulturowe $\mathrm{i}$ tworzenie oryginalnych modeli transformacyjnych opracowywanych w czasach II RP służyć miały przełamywaniu marginalizacji kraju odziedziczonej po czasach zaborów oraz gwarantować jego polityczną niepodległość. Partykularny i odpowiadający na lokalne uwarunkowania charakter tych modeli warto podkreślić i docenić, zamiast traktować je jako przykład prowincjonalizmu i niedostosowania do standardów obowiązujących w „centrum”. Warto także przemyśleć przyznawanie awangardzie, jako jedynej tak eksponowanej, roli w procesach modernizacyjnych i dostrzec ich wielowątkowość, a przez to także akceptację na szerszą skalę niż tylko wśród zwolenników awangardowego radykalizmu. Historia sztuki XX wieku, dostrzegając te problemy i analizując konsekwencje „zwrotu modernistycznego”, może dzięki temu pokazywać doświadczenie nowoczesności jako element kluczowy dla współczesnego definiowania kanonu kultury polskiej, doceniając w tym procesie eksponowaną rolę modernistycznej architektury i jej wartość dla polskiego dziedzictwa.

\section{BIBLIOGRAFIA}

Adamek K. (red.), Od niepodległości do nowoczesności. Centralny Okręg Przemysłowy 1937-1939, Stalowa Wola 2007.

B ożek G. (red.), Architektura modernistyczna Katowic i innych miast polskiego i czeskiego Śląsk, Katowice 2002.

Chmielewska A., W stużbie państwa, społeczeństwa i narodu: „państwowotwórczy” artyści plastycy w II Rzeczypospolitej, Warszawa 2006.

Furtak M., Centralny Okręg Przemysłowy (COP) 1936-1939. Architektura i urbanistyka. Kraj, region, miasto, fabryka, osiedle, budynek, Łódź 2014.

Garanty A. (red.), COP dla przyszłości. Ludzie - Przemyst - Architektura (katalog wystawy w Muzeum Regionalnym w Stalowej Woli), Stalowa Wola 2008.

Huml I., Polish Art Déco, the Style of Regained Independence (the 1920s) [w:] The Art of the 1920s in Poland, Bohemia, Slovakia and Hungary, Niedzica Seminars, October 19-22 1989, Kraków 1991, s. 11-19.

${ }^{29}$ Pisze o tym w artykule A. Szczerski, Historia sztuki II Rzeczypospolitej - perspektywy badawcze, „Rocznik Historii Sztuki” 2018, t. XLIII, s. 5-9. 
Jurkiewicz-Zej dows ka A., Wilk os z P. (red.), Sztuka Legionów Polskich, katalog wystawy Muzeum Narodowe w Krakowie, Kraków 2017.

Kitow ski S., Gdynia, miasto z morza i marzeń, Gdynia 1997.

Ko strzyńs ka-Miłos z A.,Polskiemeble 1918-1939.Forma-funkcja-technika, Warszawa 2005.

Kozina I., Chaos i uporzadkowanie. Dylematy architektoniczne na przemysłowym Górnym Ślasku w latach 1763-1955, Katowice 2005.

Król A., Rafał Malczewski: Centralny Okręg Przemysłowy - reportaż malarski 1938, Stalowa Wola 2008.

Luba I., Duch romantyzmu i modernizacja: sztuka oficjalna Drugiej Rzeczypospolitej, Warszawa 2012.

Milewska W., Zi entara M., Sztuka Legionów Polskich i jej twórcy 1914-1918, Kraków 1999.

Nowakowska-Sito K. (red.), Wyprawa w 20-lecie, wystawy w Muzeum Narodowym $w$ Warszawie, Warszawa 2008.

Odorowski W., Architektura Katowic w latach międzywojennych 1922-1939, Katowice 1994.

Olszewski A.K., Nowa forma $w$ architekturze polskiej 1900-1925, Warszawa-Wrocław 1967.

Ps zczółkow ski M., Kresy nowoczesne. Architektura na ziemiach wschodnich II Rzeczypospolitej 1921-1939, Łódź 2016.

Ruszczyń ska M., Wystawa pracy kobiet [w:] Powszechna Wystawa Krajowa w Poznaniu w roku 1929, dzieło zbiorowe pod kierownictwem dr. Stanisława Wachowiaka, t. IV, Poznań 1930.

Sieradzka A., Art Déco jako styl państwowy II Rzeczpospolitej - architektura, wnętrza „Ładu” i produkcja przemystowa [w:] Encyklopedia Art Déco, Warszawa 2002, s. 207220.

Sieradzka A. (red.), Miasto Stalowa Wola. Unikatowy zespół urbanistyczno-architektoniczny z końca lat 30. XX wieku, Stalowa Wola 2008.

Sołtysik M.J., Gdynia, miasto dwudziestolecia międzywojennego. Urbanistyka i architektura, Warszawa 1993.

Sołtysik M.J., Na styku dwóch epok. Architektura gdyńskich kamienic okresu międzywojennego, Gdynia 2003.

So snow sk a J., Poza kanonem. Sztuka polskich artystek 1880-1939, Warszawa 2003.

S z c zers ki A., Modernizacje. Sztuka i architektura w nowych państwach Europy Środkowo-Wschodniej, 1918-1939, Łódź 2010.

Świerz-Zaleski S., Zameczek w Wiśle, „Sztuki Piękne” 1931, t. 7, s. 59-61.

Treter M., Polska sztuka dekoracyjna. Z powodu książki Jerzego Warchałowskiego, „Warszawianka" 1928, nr 98.

Turows ki A., Budowniczowie świata, Kraków 2000.

Wa silew sk a D., Mieczysław Treter: Estetyk, krytyk sztuki oraz , szara eminencja” międzywojennego życia artystycznego w Polsce, Kraków 2019. 